\title{
Differences in the sugar composition of the honeydew of polyphagous brown soft scale Coccus hesperidum (Hemiptera: Sternorrhyncha: Coccoidea) feeding on various host plants
}

\author{
Katarzyna GOLAN ${ }^{1}$ and AgnieszKa NAJDA ${ }^{2}$ \\ ${ }^{1}$ Department of Entomology, University of Life Sciences in Lublin, Leszczyńskiego 7, 20-069 Lublin, Poland; e-mail: \\ katarzyna.golan@up.lublin.pl \\ ${ }^{2}$ Department of Vegetable and Medicinal Plants, University of Life Sciences in Lublin, Leszczyńskiego 58, 20-068 Lublin, Poland
}

Key words. Coccoidea, Coccus hesperidum, brown scale insects, honeydew, host plants, soft scale, sugar composition

\begin{abstract}
Plant chemical composition is an important determinant of host plant-insect interactions. For many insects sugars are the main factors determining the acceptability of a plant. This study investigated changes in plant chemical composition and differences in sugar composition of different host plants induced by the feeding of Coccus hesperidum L. (Hemiptera: Sternorrhyncha: Coccoidea). Present in plant extracts and honeydew there were three monosaccharide sugars: glucose, fructose and arabinose, and one disaccharide - sucrose. Arabinose was only found in extracts of Ficus benjamina plants. The sugar content of the honeydew was greater than in the extracts of control plants and lower than that in the extracts of infested plants. The honeydew collected from $C$. hesperidum feeding on the three plant species differed significantly in sugar content. Extracts of coccid infested plants of the three species used in this study contained more sugar than the un-infested control plants. The results show that honeydew composition of scale insects differ and the differences reflect the chemical composition of the host plants.
\end{abstract}

\section{INTRODUCTION}

Plant chemical composition is a crucial determinant of host plant-insect interactions. In plant tissues, there are about 200,000 metabolites and the number in each species fluctuates at or around 15,000 (Ferne, 2007). Among such a large number of biomolecules, phago-stimulants such as amino acids and saccharides play an important role in the interaction between herbivorous insects and their host plants (Bach, 1991; Girousse \& Bournoville, 1994; Sempruch, 2010). Hemiptera feed on phloem sap and excrete the unassimilated components of sap in the form of honeydew. Among the primary metabolites, sugars are one of the main factors determining the acceptability of a plant as food for insects. They are also a major nutrient and essential feeding stimulants for many insect species (Harborne, 1997; Oleszek et al., 2001, Sempruch, 2010). Insufficient or an imbalance in the nutrients in plants may have a negative effect, particularly on the demographic parameters of insects, causing a decline in fertility, an increase in mortality and a prolongation of their life cycle (Boczek, 1992; Leszczyński, 2001). The low concentration of sugars in plants is one of the most important determinants of their resistance to pests (lack of acceptance). On the basis of the sugar content of plants and the honeydew excreted it is possible to select species or varieties of plants resistant to harmful scale insects. Insects of the suborder Sternorrhyncha that feed on the insect-resistant plants produce less honeydew containing less sugar than those that feed on susceptible cultivars or species (Harborne, 1997). There is little knowledge of the process of production of honeydew by scale insects and few studies that use modern analytical techniques, with most of the studies on the honeydew produced by aphids (Bogo \& Mantle, 2000).

The soft brown scale attacks a wide variety of field, ornamental and greenhouse plants worldwide (Zimmerman, 1948). In Poland Coccus hesperidum L. is one of the most harmful of the greenhouse scale insects. It is found in the majority of green- houses and causes a significant decrease in the condition of plants and their decorative value because of mechanical and physical damage (Dziedzicka, 1988, 1990; Łagowska, 1995). The soft brown scale excretes onto the leaves and fruit of its host plant more honeydew than any other species (Copland \& Ibrahim, 1985). Honeydew coats the plant surface with a thin, impermeable film, to which adhere saprophytic fungi, dust and other pollutants. Moreover, ants and other insects are attracted to and thrive on honeydew, the presence of which greatly reduces the attractiveness of plants. Although $C$. hesperidum is the most common and harmful scale insect infesting greenhouse ornamental plants, little is known about the composition of the honeydew excreted by this species (Bogo \& Mantle, 2000).

The honeydew collected from one species of scale insect feeding on three different host plants was analyzed and its sugar composition compared with that of an extract of the plants on which it fed. Qualitative and quantitative analyses were carried out on extracts of uninfested plants, infested plants and the honeydew excreted by $C$. hesperidum feeding on the host plants studied.

\section{MATERIAL AND METHODS}

\section{Plant and insect material}

Experiments were carried out in a laboratory of the Department of Entomology, University of Life Sciences in Lublin (Poland). The material studied consisted of three plant species: Citrus limon var. Ponderosa, Ficus benjamina and Nephrolepis biserrata, each ca $50-60 \mathrm{~cm}$ tall and grown in pots of $15 \mathrm{~cm}$ diameter filled with a standard horticultural substrate. Three plants of each species were used in every stage of the study. These plants were artificially infested with the polyphagous pest of greenhouse ornamental plants, $C$. hesperidum, which has a high rate of honeydew production. A thin wooden spatula was used to transfer the first-instar nymphs (crawlers) of this scale insect from a laboratory culture to the experimental plants. The 

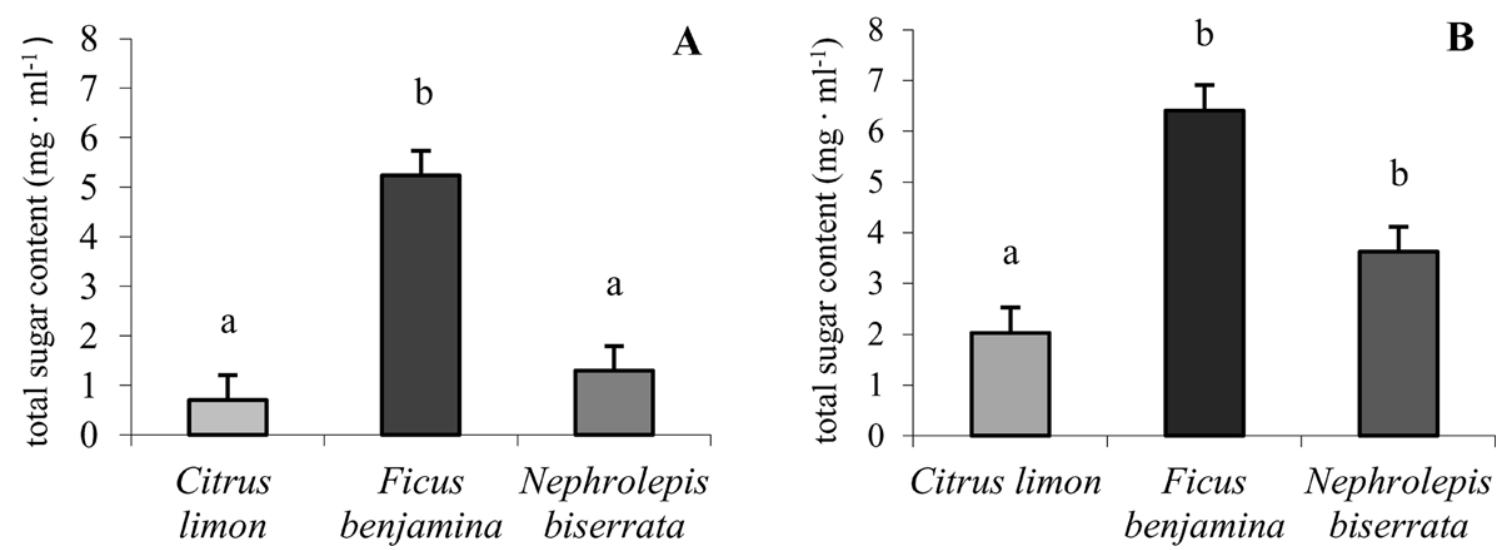

Fig. 1. Total sugar content $\left(\mathrm{mg} \cdot \mathrm{ml}^{-1}\right)$ of extracts of three species of un-infested plants (A) and of the same species of plants infested with scale insects (B). Means with the same letter do not differ significantly at $\mathrm{p}<0.05$ (Tukey test).

analysis of plant extracts was performed 6 months after the plants were experimentally infested. Air humidity and temperature during the experiment, measured using a hygrothermograph, was $75-80 \%$ and $20-22^{\circ} \mathrm{C}$, respectively. The observation was conducted in a laboratory $( \pm 12 \mathrm{~L}: 12 \mathrm{D})$, for 24 continuous hours.

\section{Analysis of plant extracts and sugar composition of hon- eydew}

Qualitative and quantitative analyses of sugars were carried out at the Vegetable and Medicinal Resources Quality Control Laboratory, Department of Vegetable and Medicinal Plants, University of Life Sciences in Lublin (Poland). Water extracts of the three plant species (un-infested and infested) and the honeydew excreted by scale insects feeding on these plants was the material used in this study. Leaves of the plants were used to obtain the plant extracts. Honeydew was collected in Petri dishes, each placed for $24 \mathrm{~h}$ directly under parts of the plants infested with scale insects. Forty to fifty-five petri dishes of honeydew per plant species were collected for the comparative analysis. Plant extracts and honeydew were prepared and purified using the SPE method. HPLC chromatographic analysis of sugars was performed in reversed-phase, using a liquid chromatograph Lachom-Merck equipped with a refractometric detector RID (L-7450), pump (L-7100), degazer (L-7612), injection loop $(20 \mathrm{ml})$, thermostat (L-7360), injection valve Rheodyne and LiChrocart $\mathrm{NH}_{2}$ cartridge $(150 \mathrm{~mm} \times 4 \mathrm{~mm})$ filled with grains of $\mathrm{dp}=5 \mathrm{~mm}$ as the stationary phase. Extracts were analyzed at $80^{\circ}$ with acetonitrile-water $(80 \%, v / v)$ as the mobile phase and a flow rate of $1 \mathrm{ml} \cdot \mathrm{min}^{-1}$. The identification of sugars was carried out by comparing their retention times $\left(t_{R}\right)$ with those of standards (Najda, 2004). The calculations of the relative sugar concentrations presented in the results were based on the absolute concentrations in the respective samples. Concentrations of sugars were determined from the HPLC integration of the peak area.

\section{Statistical analysis}

For all Statistical analysis of the results, the software package Statistica 9,1 (StatSoft, Tulsa, USA) was used. ANOVA with Tukey simultaneous test was applied, with $\mathrm{p}<0.05$. All analyses were run in triplicate.

\section{RESULTS}

\section{Sugar content and concentration in the extracts of the} various host plants of $C$. hesperidum

The total content of the sugars analyzed in the water extracts of the leaves of the control plants varied from $0.704 \mathrm{mg} \cdot \mathrm{ml}^{-1}$
(C. limon) to $5.237 \mathrm{mg} \cdot \mathrm{ml}^{-1}(F$. benjamina). Sugar content of the extracts of $F$. benjamina was considerably greater than that of the other plant species tested (Fig. 1A). The sugar content of the extracts of the plants infested with scale insects was greater than that in the extracts of the control plants (Fig. 1A, B). The total content of sugars in plants infested by scale insects ranged from $2.031 \mathrm{mg} \cdot \mathrm{ml}^{-1}$ for $C$. limon to $6.411 \mathrm{mg} \cdot \mathrm{ml}^{-1}$ for $F$. benjamina. The sugar content in the extracts of the lemon plant was significantly different from that in the extracts of the other plant species. Comparative analysis of sugar contents of samples from

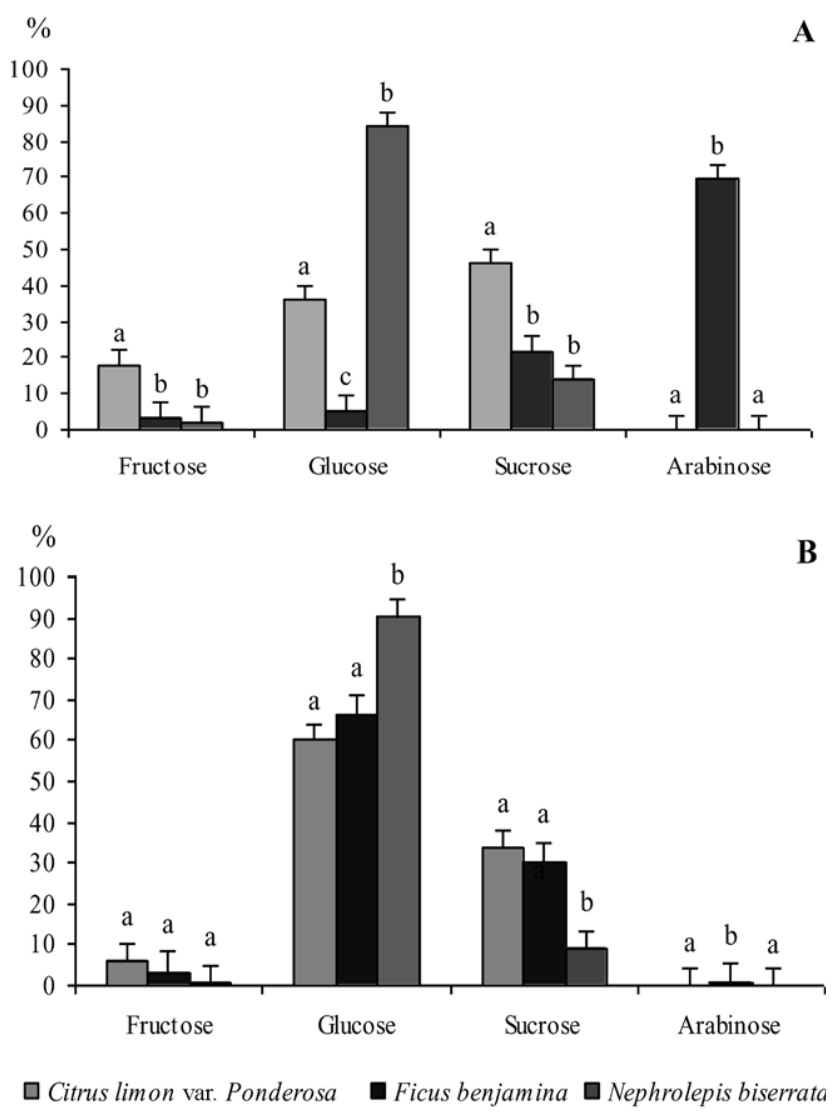

Fig. 2. Percentage of particular sugars in water leaf extracts of three species of un-infested control plants (A) and coccid infested plants (B). Means with the same letter do not differ significantly at $\mathrm{p}<0.05$ (Tukey test). 


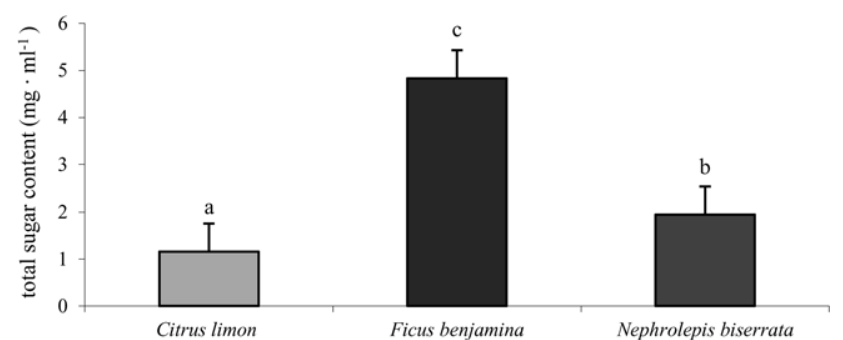

Fig. 3. Total sugar content of the honeydew of $C$. hesperidum. Means with the same letter do not differ significantly at $\mathrm{p}<0.05$ (Tukey test).

$F$. benjamina and $N$. biserrata did not differ significantly (Fig. 1B).

This analysis of the sugars revealed the presence of three monosaccharides: glucose, fructose and arabinose, and one disaccharide - sucrose. In the control plants, glucose in the extracts of $N$. biserrata accounted for $83.9 \%$ of the sugar content. The second most abundant sugar was sucrose in the extracts of $C$. limon $(46.2 \%)$. The amount of fructose in extracts of control plants was highest in C. limon (17.9\%) (Fig. 2A). Glucose was the predominant sugar in the extracts of plants colonized by scale insects, irrespective of the plant species. The percentage of glucose ranged from $60.1 \%$ in extracts of $C$. limon to $90.4 \%$ in those of $N$. biserrata (Fig. 2B). Sucrose content of extracts of infested plants was slightly lower. Highest percentage sucrose content was recorded for C. limon (33.8\%) and $F$. benjamina $(30.2 \%)$ and the lowest for $N$. biserrata $(9 \%)$ (Fig. 2B). Arabinose was found only in extracts of $F$. benjamina with the highest concentration in control plants $(69.5 \%)$ and a considerably lower concentration in plants infested with scale insects $0.6 \%$ of all the sugars identified (Fig. 2A, B).

The content and concentration of sugars in the honeydew excreted by $C$. hesperidum feeding on different species of host plants

The content of sugars in the honeydew produced by $C$. hesperidum feeding on the three host species differed significantly. The sugar content of the honeydew of $C$. hesperidum feeding on $F$. benjamina was the highest $\left(4.833 \mathrm{mg} \cdot \mathrm{ml}^{-1}\right)$ and that of those feeding on $C$. limon the lowest $\left(1.159 \mathrm{mg} \cdot \mathrm{ml}^{-1}\right)$ (Fig. 3). There were four sugars in the honeydew of $C$. hesperidum: glucose, fructose, arabinose and sucrose (Fig. 4). Fructose, glucose and sucrose were present in the honeydew of $C$. hesperidum feeding on $C$. limon and $N$. biserrata. Arabinose was found only in the honeydew of $C$. hesperidum feeding on $F$. benjamina. Glucose was predominant among the sugars identified in $C$. hesperidum honeydew irrespective of the species of host plant the scale

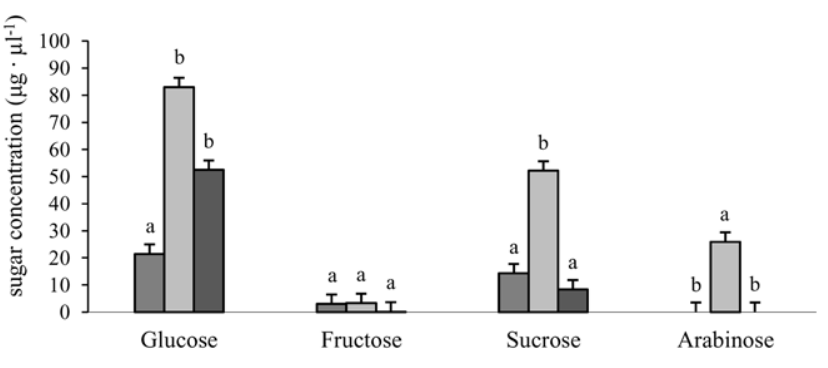

Fig. 4. Sugar concentration (in $\mu \mathrm{g} \cdot \mu \mathrm{l}^{-1}$ ) in the honeydew of C. hesperidum. Means with the same letter do not differ significantly at $\mathrm{p}<0.05$ (Tukey test).

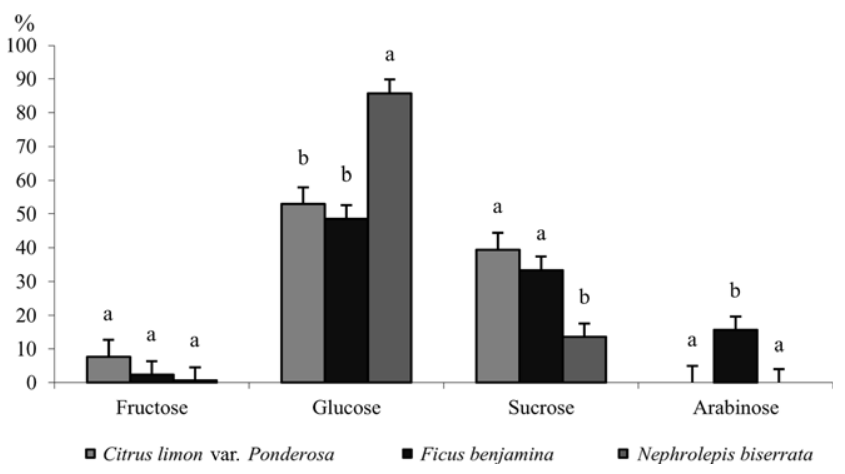

Fig. 5. Percentage of particular sugars in the honeydew of $C$. hesperidum that fed on the three different host plants. Means with the same letter do not differ significantly at $\mathrm{p}<0.05$ (Tukey test).

insect fed on, with the concentration ranging from $21.42 \mu \mathrm{g}$. $\mu 1^{-1}$ ( $N$. biserrata host plant) to $82.96 \mu \mathrm{g} \cdot \mu 1^{-1}$ (F. benjamina host plant). In all the samples analyzed, the concentration of fructose was the lowest of all the sugars identified (Fig. 4).

Percentage of particular sugars in the honeydew of $C$. hesperidum was similar irrespective of the host plant. Glucose was the predominant sugar recorded in the honeydew of $C$. hesperidum irrespective of the host plant. Glucose content was particularly high $(85.8 \%)$ in the honeydew of this scale insect when it fed on $N$. biserrata. The content of glucose in honeydew collected from scale feeding on $C$. limon and $F$. benjamina did not differ significantly and was relatively low (Fig. 5).

The analysis of the sugar content of the extracts of three control plant species, of these plants infested with scale insects and of the honeydew excreted by $C$. hesperidum feeding on these plants revealed differences between the samples collected from C. limon and N. biserrata. Extracts of control plants of all species had a lower content of sugars than those of infested plants. High sugar contents were recorded for all the extracts of plants infested with scale insect and differed significantly from that of the extracts of control plants and in honeydew, regardless of host plant species. In $F$. benjamina the content of sugars in plant extracts was slightly higher in the control than in the honeydew, but not significantly so. In honeydew excreted by $C$. hesperidum feeding on $C$. limon and $N$. biserrata the sugar content was higher in relation to that in the extracts of control plants and lower in relation to the extracts of plants infested with scale insects (Fig. 6).

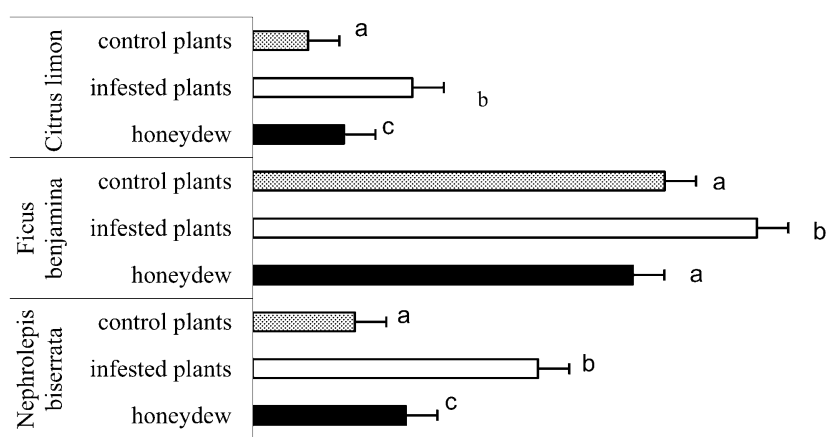

Fig. 6. Total sugar content $\left(\mathrm{mg} \cdot \mathrm{ml}^{-1}\right)$ in the extracts of control and infested plants, and the honeydew of $C$. hesperidum that fed on those plants. Means with the same letter do not differ significantly at $\mathrm{p}<0.05$ (Tukey test). 


\section{DISCUSSION}

Insects of the order of Hemiptera feed on phloem sap and consequently excrete the excess sugar and water in the form of honeydew. The process of honeydew production is welldocumented but most publications focus on aphids (Ashford et al., 2000; Fischer \& Shingleton, 2001; Wool et al., 2006) and little is known about this process in scale insects. According to the literature, honeydew composition differs not only among aphid species but also within aphid species depending on host plant (Fischer \& Shingleton, 2001). Different species of aphids sharing the same host are likely to utilize the same phloem sap and differences in sugar composition of the honeydew may result from differences in the metabolism of the insects, which results in differences in the quality and quantity of honeydew sugars (Völkl et al., 1999; Fischer \& Shingleton, 2001; Wool et al., 2006). Chromatographic analysis of honeydew excreted by $C$. hesperidum feeding on three different plant species revealed differences in the content and composition of the sugars. A study on whiteflies by Hendrix et al. (1992) highlights the differences in sugar composition of honeydew excreted by Bemisia tabaci (Gennadius, 1889) and Trialeurodes vaporariorum (Westwood) feeding on different host plants. Many studies on aphids also confirm that the chemical composition of honeydew differs depending on the aphid species and host plant (Völkl et al., 1999; Fischer et al., 2005). In the present study, there were significant differences in the total sugar content of the honeydew of the scale insect feeding on the three different host plants. The highest total sugar content was recorded in the honeydew excreted by $C$. hesperidum feeding on $F$. benjamina and the lowest when feeding on $C$. limon. A similar relationship was recorded in total sugar content of plant extracts. Over 20 sugars are recorded in the honeydew of aphids (Wool et al., 2006) According to many authors, glucose and fructose are basic components of the honeydew of these sap sucking insects (Wilkinson et al., 1997; Fischer et al., 2005; Wool et al., 2006). These sugars are present in honeydew in different proportions depending on the insect species and host plant. This study on $C$. hesperidum revealed that the honeydew of this scale insect contains three monosaccharides (glucose, fructose and arabinose) and one disaccharide (sucrose). As in the study by Wool et al. (2006), the sugar that predominated in honeydew, regardless of host plant, was glucose. It occurred in different concentrations but was particularly abundant in the case of honeydew collected from the scale feeding on $N$. biserrata. This contrasts with the results of Bogo et al. (1999) for an un-described species of scale insect, closely related to Stigmacoccus asper. In the honeydew of this species glucose was less abundant than sucrose and fructose. There was characteristically very little fructose in the honeydew of $C$. hesperidum. A low level of fructose in the honeydew excreted by whiteflies is regarded as normal (Hendrix \& Salvucci, 1998). According to these authors, fructose, unlike glucose, is absorbed in the gastrointestinal tract of whiteflies and then serves as the substrate for polyol sorbitol biosynthesis. A low content of fructose in the honeydew of $C$. hesperidum may result from a metabolic specificity of this insect. Ashford et al. (2000) report a different sugar metabolism in aphids. They suggest that the fructose moiety of ingested sucrose seems to be very efficiently and preferentially respired by the aphid, while the glucose moiety is incorporated into disaccharides. Sucrose is a main component of plant sap and an important source of metabolic energy for insects (Sempruch \& Ciepiela, 1999; Leszczyński, 2001; Wool et al., 2006). It affects the development, fertility and mortality of aphids (Leszczyński, 2001). In a study of the content of disaccharides in the honeydew of an undescribed species of scale insect, closely related to Stigma- coccus asper, sucrose was found to be the principal sugar in honeydew (Bogo et al., 1999). Sucrose was present in the honeydew of $C$. hesperidum and plant extracts, but in all cases in smaller amounts than glucose. This study revealed it was present in all plant extracts and at greater concentrations in those of plants infested with scale insects. Sucrose was most abundant in extracts of $F$. benjamina infested with scale insects and in the honeydew they produced when feeding on this host plant. Sucrose is a disaccharide, which can be hydrolyzed by sucrase, yielding fructose and glucose and this may explain the presence of sucrose in smaller amounts than glucose. In the honeydew of aphids and whiteflies there are similarly low quantities of sucrose, which is also associated with the split into monosaccharide units (Salvucci et al., 1997). Arabinose was present only in the honeydew excreted by $C$. hesperidum feeding on $F$. benjamina. It was also found in extracts of both the control and infested plants of $F$. benjamina. Arabinose is an aldose monosaccharide and a component of the polysaccharides in plant cell walls, as well as gums, pectins and plant mucilage, in small quantities, and is found in plants of the family Moraceae (Jeong et al., 2009). Research on aphids (Fischer \& Shingleton, 2001) and the present results indicate that the biochemical composition of honeydew varies within a species of insect depending on the host plant. According to the literature (Völkl et al., 1999; Fischer et al., 2005) the composition of honeydew is determined by the species of aphid that produced it, some age - specific patterns and the plant species on which the aphid feeds. In a similar study conducted on aphids (Fischer \& Shingleton, 2001), differences in chemical composition of the honeydew are explained inter alia by genetic variation between insect populations. However, differences in the chemical composition of host plant sap appear to be a primary factor influencing the diversity in the biochemical composition of honeydew, which is confirmed by the results of this study and those of other authors.

ACKNOWLEDGMENTS. This research project (N N310 449738) was financed by the Ministry of Science and Higher Education.

\section{REFERENCES}

Ashford D.A., Smith W.A. \& Douglas A.E. 2000: Living on a high sugar diet: the fate of sucrose ingested by a phloem feeding insect, the pea aphid Acyrthosiphon pisum. J. Insect Physiol. 46: 335-341.

BACH C.E. 1991: Direct and indirect interactions between ants (Pheidole megacephala), scales (Coccus viridis) and plants (Pluchea indica). Oecologia 87: 233-239.

BoCZEK J. 1992: Odporność roślin na szkodniki i metody jej wykorzystywania. [Plant resistance to pests and methods of its use.] In Niechemiczne metody zwalczania szkodników roślin. [Non-chemical control methods of plant pests.] Warsaw Agricultural University, Warsaw, pp. 98-130 [in Polish].

Bogo A. \& Mantle P. 2000: Disaccharides in the honeydew of Coccoidea scale insects: Coccus hesperidum L. and a new Stigmacoccus sp. in Brazil. An. Soc. Entomol. Brasil 29: 589-595.

Bogo A., Watson G.W., Mantle P.G. \& Mottana G.M. 1999: Honeydew sugars eliminated by Stigmacoccus sp. nr. Asper Hempel (Hemiptera: Margarodidae) feeding on Leguminous trees in Brazil. Entomologica 33: 275-278.

Copland M.J.W. \& Ibrahim A.G. 1985: Chapter 2.10 Biology of glasshouse scale insects and their parasitoids. In Hussey N.W. \& Scopes N. (eds): Biological Pest Control The Glasshouse Experience. Cornell University Press, Ithaca, NY, pp. 87-90. 
Dziedzicka A. 1988: Czerwce szklarniowe (Coccinea) Polski. [The greenhouses scale insects of Poland]. Rocz. Nauk. Dydakt. (Kraków) 123: 79-91 [in Polish].

DzIEDzICKA A. 1990: The characteristic of scale insects (Coccinea) occurring in Polish greenhouses. Part II. Coccidae. Acta Biol. Cracov. (Series I) 32: 17-27.

FERNE A.R. 2007: The future of metabolic phytochemistry: larger number of metabolites, higher resolution, greater understanding. Phytochemistry 68: 2861-2880.

Fischer M.K. \& Shingleton A.W. 2001: Host plant and ants influence the honeydew sugar composition of aphids. Funct. Ecol. 15: 544-550.

Fischer M.K., VöLKL W. \& Hoffmann K.H. 2005: Honeydew production and honeydew sugar composition of polyphagous black bean aphid, Aphis fabae (Hemiptera: Aphididae) on various host plants and implications for ant-attendance. Eur. J. Entomol. 102: 155-160.

Girousse C. \& Bournoville R. 1994: Role of phloem sap quality and exudation characteristics on performance of pea aphid grown on Lucerne genotypes. Entomol. Exp. Appl. 70: $227-235$.

Harborne J.B. 1997: Ekologia Biochemiczna. Wydawnictwo Naukowe PWN, Warszawa, $351 \mathrm{pp}$.

Hendrix D.L. \& Salvucci M.E. 1998: Polyol metabolism in Homopterans at high temperatures: accumulation of mannitol in aphids (Aphididae: Homoptera) and sorbitol in whiteflies (Aleyrodidae: Homoptera). Compar. Biochem. Physiol. (A) 129: 487-494.

Hendrix D.L., Wei Y. \& LegGet J.E. 1992: Homopteran honeydew is determined by both the insect and the plant species. Compar. Biochem. Physiol. 101: 23-27.

JeONG M.R., Kiм H.Y. \& ChA J.D. 2009: Antimicrobial activity of methanol extract from Ficus carica leaves against oral bacteria. J. Bacteriol. Virol. 39: 97-102.

ŁagowsKa B. 1995: Występowanie czerwców (Homoptera, Coccinea) na doniczkowych roślinach ozdobnych w szklarniach. [Occurrence of scale insects (Homoptera, Coccinea) on pot ornamental plants in greenhouses). Mat. Ogólnopol. Konf. Nauk. "Nauka Praktyce Ogrodniczej”. AR Lublin, pp. 375-378 [in Polish].

LESZCZYŃSKI B. 2001: Rola allelozwiązków w oddziaływaniach owady - rośliny. [The role of the interactions between allelocompounds and insects-plants.] In Oleszek W., Głowniak K.,
Leszczyński B. (eds): Biochemiczne oddzialywania środowiskowe. [Biochemical Environmental Interactions.] Akademia Medyczna, Lublin, pp. 61-85 [in Polish].

NAJDA A. 2004: Plonowanie $i$ ocena fitochemiczna roślin $w$ różnych fazach wzrostu dwu odmian selera naciowego (Apium graveolens L. var. dulce Mill./Pers.). [Yield and Photochemical Value of Plants in Various Stages of Growth of Two Cultivars of Celery (Apium graveolens L. var. dulce Mill. /Pers).] PhD thesis, University of Life Science in Lublin, 249 pp. [in Polish].

OleszeK W., GŁowniaK K. \& Leszczyński B. 2001: Biochemiczne oddziaływania środowiskowe. [Biochemical Environmental Interactions.] Akademia Medyczna, Lublin, pp. 61-85 [in Polish].

Salvucci M.E., Wolfe G.R. \& Hendrix D.L. 1997: Effects of sucrose concentration on carbohydrate metabolism in Bemisia argentifolii: biochemical mechanism and physiological role for trehalose synthesis in the silverleaf whitefly. J. Insect Physiol. 43: 457-464.

SEMPRUCH C. 2010: Rola zwizkw azotowych w interakcjach midzy rolinami a rolinoernymi owadami. [The role of nitrogen compounds in the interaction between plants and herbivorous insects.] Kosmos 59: 99-209 [in Polish].

Sempruch C. \& Ciepiela A.P. 1999: The role of nitrogen and soluble carbohydrates in the interaction between selected species of winter cereals, and grain aphid (Sitobion avenae (F), Homoptera: Aphididae). Ann. Agricult. Sci. (Ser. E, Plant Prot.) 28: 29-35

VölkL W., Woodring J., Fischer M., Lorenz M.W. \& HoffMANN K.H. 1999: Ant-aphid mutualism: The impact of honeydew production and honeydew sugar composition on ant preferences. Oecologia 118: 483-491.

Wilkinson T.L., Ashford D.A., Pritchard J. \& Douglas A.E 1997. Honeydew sugars and osmoregulation in the pea aphid Acyrthosiphon pisum. J. Exp. Biol. 200: 2137-2143.

Wool D., Hendrix D.L. \& Shukry O. 2006: Seasonal variation in honeydew sugar content of galling aphids (Aphidoidea: Pemphigidae: Fordinae) feeding on Pistacia: host ecology and aphid physiology. Basic Appl. Ecol. 7: 141-151.

Zimmermann E.C. 1948: Insects of Hawaii. Vol. 5, Homoptera: Sternorrhyncha. University of Hawaii Press, Honolulu, 464 pp.

Received January 19, 2011; revised and accepted July 7, 2011 